\title{
The Attitude of Primary School Teachers towards STEM Education
}

\author{
Wong Kah Wei ${ }^{1}$, Siti Mistima Maat ${ }^{2}$ \\ ${ }^{1}$ Faculty of Education, Universiti Kebangsaan Malaysia, Bangi, Selangor, Malaysia \\ ${ }^{2}$ Research Center of Teaching and Learning, of Education, Universiti Kebangsaan Malaysia, Bangi, \\ Selangor, Malaysia
}

\begin{abstract}
The main purpose of this study was to determine the level of teachers' attitude towards STEM education as well as the attitudinal disparity between male and female students. The questionnaire which has 29 items using a 5-point Likert scale was administered to 310 primary school mathematics teachers. Descriptive analysis and independent t-tests were applied to solve the research questions. The results showed that the attitude of the primary school mathematics teacher was moderate and there were no significant differences in the attitude of the primary school mathematics teacher by gender. Overall, the findings of this study are expected to raise awareness among the relevant parties. Efforts from the ministry is a vital need to enhance teachers' attitude towards STEM education and fulfil the national interest in producing a competitive generation.
\end{abstract}

Keywords - STEM, attitude, teacher, mathematics, primary school

\section{Introduction}

Mathematics has become common in our everyday life such as shopping activities, estimation of fasting hours, housing designs, and more.

DOI: $10.18421 /$ TEM93-53

https://doi.org/10.18421/TEM93-53

Corresponding author: Siti Mistima Maat, Teaching and Learning Innovations, Faculty of Education, Universiti Kebangsaan, Malaysia.

Email: sitimistima@ukm.edu.my

Received: 13 April 2020.

Revised: 12 August 2020.

Accepted: 19 August 2020.

Published: 28 August 2020.

(c) BY-NC-ND(C) 2020 Wong Kah Wei \& Siti Mistima Maat; published by UIKTEN. This work is licensed under the Creative Commons Attribution-NonCommercial-NoDerivs 4.0 License.

The article is published with Open Access at www.temjournal.com
Therefore, mathematics is part of the cultural heritage that prioritizes mathematical concepts but also needs to work in-line with sophisticated tools to keep up with the advancement of time [14]. Human beings cannot be able to distinguish between mathematical and other knowledge when solving everyday problems. Without a set of knowledge, problems cannot be solved because it is a combination of different aspects of knowledge. Thus, STEM education comes to light.

STEM education is no longer a fairy tale in this new era, especially for educators who are closely related to the development of the education system. STEM education integrates four disciplines, namely science, technology, engineering, and mathematics into one unit to produce a new generation of specialists in STEM [1]. The field of STEM will be the main occupation in the future [23]. Many countries have broadly adopted STEM education in their own countries [23] as they realize the needs and importance of this field. STEM has evolved exponentially and has become a talk of the town worldwide.

STEM combines four disciplines and is supported by 21 st-century skills [6]. This STEM education practically replaces traditional teaching methods with a more student-centered teaching approach [8]. Students can acquire new knowledge and solve problems presented by STEM teachers through projects, inquiry approaches, critical and crisis skills, collaboration, and so on, but most importantly, student learning should be in line with their daily life. Students' activities involve social elements, cultural factors, and physical interactions among them in the learning process. Therefore, educators will have the confidence to believe that STEM education can produce skilled and competitive students in the era of globalization.

However, findings from the previous studies show that the number of students graduating from the STEM field of study is decreasing [1]. The results from this critical finding are presumed to encounter a possible shortage of STEM workforce in the future 
worldwide. The country will encounter developmental issues, such as a lack of professional and skilled laborers to compete with other countries. Recent studies have clarified that the major factor contributing to the decline in STEM graduates is the anxiety of STEM students [29]. They are anxious and having difficulties in getting good grades in STEM courses. Besides, they have the misconception that it is difficult for them to pursue tertiary education if they choose to pursue a STEM-related degree [29]. Students are not passionate about STEM and their negative thoughts have been a hindrance [23] for students to pursue STEM. Stereotypical students should be given guidance by the appropriate party.

The most appropriate people to change the students' perceptions of STEM education are teachers. Teachers play a major role in their educational lives. As teachers, they are people who hold various roles such as knowledge and skills, facilitators, and student counselors in school. Therefore, teachers need to be prepared and be positive in each curriculum transformation. Teachers who are problematic in terms of attitude will have a significant impact on teaching performance and learning processes [1]. Many STEM studies are conducted from the perspective of the students, but less so from the viewpoint of the teacher [23]. Studies focusing on STEM teachers' beliefs and attitudes are extremely limited [1]. Research on teachers should be conducted to overcome this research gap.

The purpose of this research is to study the teachers' attitudes towards STEM. One of the factors that affect the output of quality STEM teachers is their attitude. Positive attitudes can lead to positive behaviors because non-measurable attitudes can be expressed through behavior [29]. Teachers' attitudes can affect the effectiveness of STEM implementation. Also, this study examined differences in the attitudes of STEM teachers based on gender. Previous studies have shown that male teachers have higher confidence compared to female teachers [17]. In other words, male teachers show a more positive attitude towards STEM.

More specifically, the objectives of this study are

1. Determine the attitude of Hulu Langat's primary school teachers towards STEM implementation.

2. Determine the differences in attitudes of Hulu Langat's primary school teachers towards STEM implementation by gender.

This study uses primary school mathematics teachers who teach in Hulu Langat region as a research sample.

\section{The Needs of STEM Education in the Globalization Era}

Mathematics is an integrated knowledge with its cultural heritage and must be essentially supported by sophisticated equipment to keep up in the living trend of the world's rapid development [14]. Mathematics cannot work alone in solving everyday problems [12]. The collaboration between mathematicians and experts in other fields to solve problems is a desideratum. For example, the flood disaster that has occurred in late 2014 in Malaysia required different experts to share and work together for this act of nature to be resolved effectively. The question that arises from this is that each expert possesses different knowledge and skills, but no single expert can associate as one with multiple abilities.

Considering the above issues, STEM education, which combines the disciplines of science, mathematics, engineering, and technology, has managed to draw the attention of educators all over the world. Since the 1990s, STEM education has been introduced by major countries such as the United States, England, and Australia in their national education system [7]. The determination to breed a new generation of adroit expertise in the four disciplines is essential with a world filled with technological sophistication challenges in the future. It is the discipline of engineering and technology that is significantly related to science and mathematics as well as STEM within its actual contexts that encourage individuals to study without borders, thus the development of STEM workforce will be thoroughly occupied.

STEM careers are a big potential profession in the future. Professionals in the field of STEM are needed to control the machines that have replaced modern human work. Individuals who fulfill potential STEM career requirements also need to be raised in significant numbers. However, studies from Australia suggest that the world is facing a problem of shortage of experts in the field of STEM, and the number of high school students who choose STEM disciplines is declining [13]. Not all STEM graduates choose STEM jobs, with only $57 \%$ of students working in STEM fields and $46 \%$ of STEM graduates leaving STEM. The results of such studies hypothesized that the issue of the demand for the STEM workforce is becoming more serious.

Malaysia is faced with the same question. The target of producing a ratio of $60 \%$ of science graduates and $40 \%$ of non-science was still unattainable until 2012, with further decline in the number of students in the STEM field [29]. The key cause of the inability to achieve the 60:40 level is due to the student's anxiety [29]. Students have a negative 
impression of STEM education that it is impossible to gain good grades in STEM. They are less interested in STEM fields and may not opt for this degree. STEM curriculum integrating the discipline of knowledge with practical experiences, has been shown to increase the curiosity and ability to learn [16] where knowledge and behaviors have also been shown to improve after going through [28].

\section{The Importance of Teacher's Attitudes Towards STEM Education}

STEM education is therefore an educational program that needs to be implemented to fulfill the ideal future of the nation's interest. Teachers are the people who are ideally adapted to implement STEM education. They play a significant role in educating the students [21]. High-quality STEM teachers are more successful in providing STEM education effectively [10] and students will enjoy studying STEM according to STEM objectives. Student's anxiety is predicted to decrease if STEM is presented by a quality STEM teacher.

A good teacher needs to possess solid knowledge and skills before delivering the lessons to the students [1]. Likewise, the expertise and abilities a teacher possesses are closely related to the teacher's attitude [2] in the implementation of the new education system. STEM teachers are observed to be more confident as their professional development progresses [16]. The attitude of teachers cannot be dismissed and plays a significant part when there is a transformation of the curriculum, whether teachers would support (positive) or oppose (negative) the reform. According to the Theory of Action Causes, attitudes influence an individual's behavior. The attitude of a teacher cannot be assessed but can be rendered into observable actions [3]. Hence, STEM teachers who intend to incorporate STEM education require the confidence and optimistic outlook when implementing STEM to students. Students who perceive STEM positively will also be influenced by optimistic behaviors and beliefs.

Teachers who teach mathematics subject that is innovative with high-level insight and strong communication needs to be positive [24] such as being motivated, being able to control stress, confident, patient, willing to take chances, always have the curiosity and concern on matters. Mathematics teachers who are prepared to change to STEM teachers should be optimistic and learn STEM open-heartedly, not easily discouraged when faced with challenges, and like to explore the unknown. Nevertheless, the findings of previous research indicate that teachers are concerned about students' safety (Jamil et al. 2018) and lack of confidence when asked to implement STEM education [4].
Feeling stressed out and depressed by a teacher will impede the success of STEM education [1].

Therefore, it is important to maintain a good disposition towards a mathematics teacher to prepare themselves for becoming a STEM teacher. Meanwhile, teachers of different genders have different attitudes toward the implementation of STEM education. Previous studies indicate that male teachers are more confident than female teachers in the implementation of STEM [16]. Male teachers are also more interested in teaching technology [15]. Technology and engineering subjects are often considered difficult resulting in the lack of confidence and interest in STEM teaching among female teachers. Nevertheless, female teachers are found to have higher curiosity and awareness compared to male teachers [19]. Female teachers also show a positive attitude towards the implementation of STEM education. Different perspectives towards the implementation of STEM are influenced by their genders. These differences can have an impact on STEM and studies need to be carried out to study the implications of this issue.

\section{Methodology}

This study uses a survey design, which is best to find out more about attitudes, opinions, behaviours, ideas and others in a certain phenomenon. The key purpose of this research was to analyse the level of attitude of primary school mathematics teachers towards STEM education. The survey results could demonstrate and generalize the characteristics of primary school mathematics students' population in Hulu Langat district concerning STEM education. Quantitative survey studies are suitable for large sample experiments and can be performed accessibly using a software.

The population of this study comprises of primary school mathematics teachers based in Hulu Langat district, in which 1600 teachers teach primary-school mathematics subjects. Cochran formula has been used to obtain optimal size samples [27]. The Cochran formula is given as follows,

$$
n_{\mathrm{o}}=\frac{Z^{2} p q}{e^{2}}
$$

where $z$ values can be obtained in $z$ tables, $p$ values are the population proportions of research questions' respondents, $q$ values can be calculated by $1-p$ and $e$ values are the desired level of precision. The population rate which contributed to the study's response was $50 \%$ and $\pm 5 \%$ is the error margin in this study. $n_{0}=(1.96)^{2}(0.5)(0.5) /(0.05)^{2}=385$, whereof the 385 represents mathematics teachers as the sample size of the study with a $95 \%$ confidence 
level. Next, the following formula below is used to obtain the optimal size sample.

$$
n=\frac{n_{0}}{1+\frac{\left(n_{0}-1\right)}{N}}
$$

With $n=385 / 1+[(384) / 1600]=310$, the optimal sample size for this study was 310 people. The random sampling method was used to obtain 310 samples from nine schools located in the Kajang and Cheras zones of Hulu Langat district. Table 1.0 presents the background demographics of the 310 respondents of the study.

Table 1. Background demographics

\begin{tabular}{|c|c|c|c|c|}
\hline Variable & Category & $\mathbf{N}$ & & $(\%)$ \\
\hline \multirow[t]{3}{*}{ Gender } & Male & 33 & & 10.6 \\
\hline & Female & 277 & & 89.4 \\
\hline & & 310 & & 100.0 \\
\hline \multirow[t]{5}{*}{ Age } & $21-30$ years & 70 & & 22.6 \\
\hline & $31-40$ years & & 158 & 51.0 \\
\hline & $41-50$ years & & 58 & 18.7 \\
\hline & $>51$ years & 24 & & 7.7 \\
\hline & & 310 & & 100.0 \\
\hline \multirow{5}{*}{$\begin{array}{l}\text { Experienced } \\
\text { in teaching } \\
\text { mathematics } \\
\text { subject }\end{array}$} & $\begin{array}{l}5 \text { years and } \\
\text { below }\end{array}$ & 93 & & 30.0 \\
\hline & 5-10 years & & 85 & 27.4 \\
\hline & $10-15$ years & & 61 & 19.7 \\
\hline & $\begin{array}{l}15 \text { years and } \\
\text { above }\end{array}$ & 71 & & 22.9 \\
\hline & & 310 & & 100.0 \\
\hline \multirow[t]{3}{*}{$\begin{array}{l}\text { Teaching } \\
\text { location }\end{array}$} & City & 292 & & 94.2 \\
\hline & Rural & 18 & & 5.8 \\
\hline & & 310 & & 100.0 \\
\hline \multirow[t]{5}{*}{$\begin{array}{l}\text { Level of } \\
\text { education }\end{array}$} & SPM & 7 & & 2.3 \\
\hline & Diploma & & 43 & 13.9 \\
\hline & Bachelor & & 239 & 77.1 \\
\hline & Master & 21 & & 6.8 \\
\hline & & 310 & & 100.0 \\
\hline \multirow{3}{*}{ Specialty } & Mathematics & & & \\
\hline & $\begin{array}{l}\text { Non- } \\
\text { Mathematics }\end{array}$ & $\begin{array}{l}34 \\
256\end{array}$ & & $\begin{array}{l}17.4 \\
82,6\end{array}$ \\
\hline & & 310 & & 100.0 \\
\hline \multirow{3}{*}{$\begin{array}{l}\text { LADAP } \\
\text { STEM } \\
\text { experience }\end{array}$} & Yes & 9 & & 2,9 \\
\hline & No & 301 & & 97.1 \\
\hline & & 310 & & 100.0 \\
\hline
\end{tabular}

\section{Questionnaire Instrument}

The research instrument used was a full-scale quantitative questionnaire. The questionnaire was adapted from the Technology, Engineering and
Mathematics (STEM) Education from the Cognitive, Affective and Behavioural Aspect [1] and was modified to fit the context and sample of the local study. The study data was referred to two experts to test the validity of the content. Language and word corrections in the item have been made at the recommendation of an expert.

The instrument is divided into two sections, part A containing 7 items related to the study demographics and part B containing measurement items. A total of 22 items in section B and a 5-point Likert scale were used. Score 1 represents "Strongly Disagree" option, score 2 represents "Disagree" option, score 3 represents the "Neutral" option, score 4 shows the "Agree" option, and score 5 shows the "Strongly Agree" option. Each item is positively stated.

A pilot study of 30 study samples was conducted to test the reliability of the instrument. Alpha Cronbach's values around 0.7 or higher are instrument items with high reliability [24]. The results showed that the study items were at a high level of reliability point of .938 . No instrument items need to be removed. The instruments of this study have achieved strong validity and reliability.

\section{Data Collection and Analysis}

310 sets of questionnaires were distributed to selected teachers in July 2019 following the approval process by the Ministry of Education, the Selangor State Education Department and the Hulu Langat District Education Office. All sets of questionnaires were successfully retrieved after two weeks with no missing value. The data collected was analysed using Statistical Package for Social Sciences (SPSS) version 23.0.

Descriptive analysis, which refers to the frequency and percentage data, were used to look at the tendency of the study sample in terms of their attitude. The overall mean for constructive attitude is often referred to as defining the attitude level towards STEM education by primary school mathematics teachers. An overall mean of 1.00 to 2.33 is considered as a low-level attitude and a mean of 2.34 to 3.67 indicates a moderate level of mathematics teachers' attitude toward STEM. Meanwhile, the mean of 3.68 to 5.00 indicates high level attitude results. The interpretation of the overall mean score according to its range (Abdullah, 2017) are shown in Table 2.0.

Table 2. Interpreted Mean Score Range

\begin{tabular}{ll}
\hline Mean Score Range & Interpretation \\
\hline $1.00-2.33$ & Low \\
$2.34-3.67$ & Medium \\
$3.68-5.00$ & High \\
\hline
\end{tabular}


Subsequently, inference analysis is used to determine the mean difference in mathematics teachers' attitudes towards STEM education based on gender. The independent t-test, also called as the two-sample t-test, is appropriate because it is used to test two classes with different features, such as gender i.e. male and female teachers.

Before the independent t-tests are performed, several assumptions were tested to check the optimum conditions so that the test can proceed. Samples were randomly selected and are independent of every score variable. The data collected is also transformed into the mean, which performs the function of an interval for conducting a parametric test analysis. Normality tests were performed to meet the third assumption. Sample sizes greater than 50 are required to perform the normality test with reference to the visual results [2]. Sample sizes greater than 300 were proposed to identify the normality from the histogram, skewness and kurtosis (Mishra et al. 2019). Therefore, Figure 1.0 shows that the data of the analysis are approaching normal, and the bell shape is almost symmetrical. All assumptions were successfully met; hence, the independent t-test is suitable to test the mean difference of mathematics teachers' attitudes toward STEM based on gender.

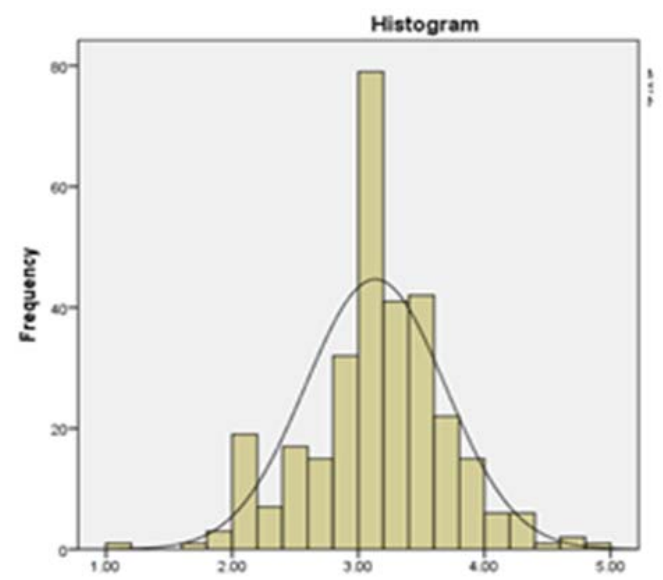

Figure 1. Mathematics teacher's attitude normality test

\section{Results}

The results of the study have shown that respondents are more likely to choose the "less agree" option. Most items in measuring the level of attitude of mathematics teachers towards the implementation of STEM education were answered by respondents with a "strongly disagree" of $50 \%$. For example, items D12 "I do not find it difficult to implement STEM Education" and D22 "I am always searching for the latest STEM Education.", there were $200(64.5 \%)$ and 190 people $(61.3 \%)$ who answered "disagree" respectively. Most of the respondents considered STEM as difficult and they are less interested in STEM-related knowledge.

However, there are two items in which the "disagree" option does not reach 50\%. 128 people $(41.3 \%)$ and 126 people $(40.6 \%)$ chose "agree" on the items "I am willing to collaborate with other subject teachers" and "I always use resources in my daily life as a learning aid" respectively. These results have shown that teachers are truly professional when carrying out their tasks as they are ready to collaborate with other teachers and concerns towards their daily life in learning.

Thus, the overall results revealed that the attitude of mathematics teachers towards STEM education is moderate $(\mathrm{m}=3.135, \mathrm{~s} . \mathrm{d}=.554)$. Table 3.0 lists the frequency and percentage of respondents based on the teachers' attitude items as well as the mean of the overall findings. 
Table 3. Frequency and percentage of items - Teacher's attitude

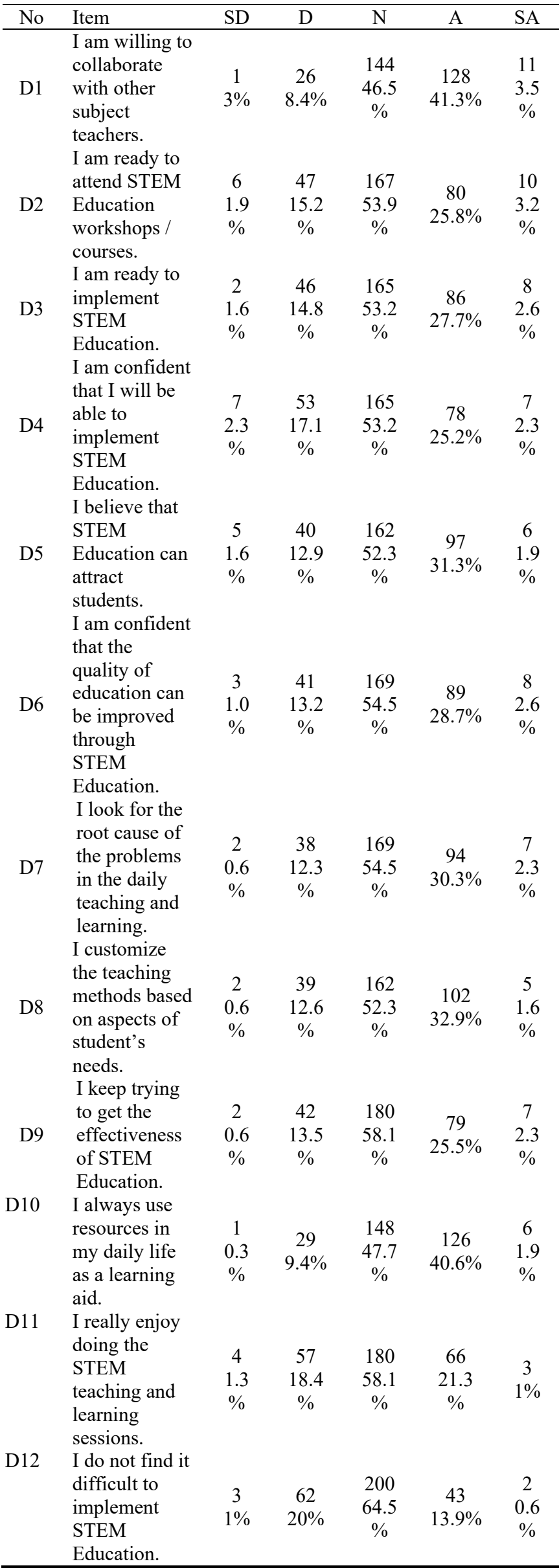

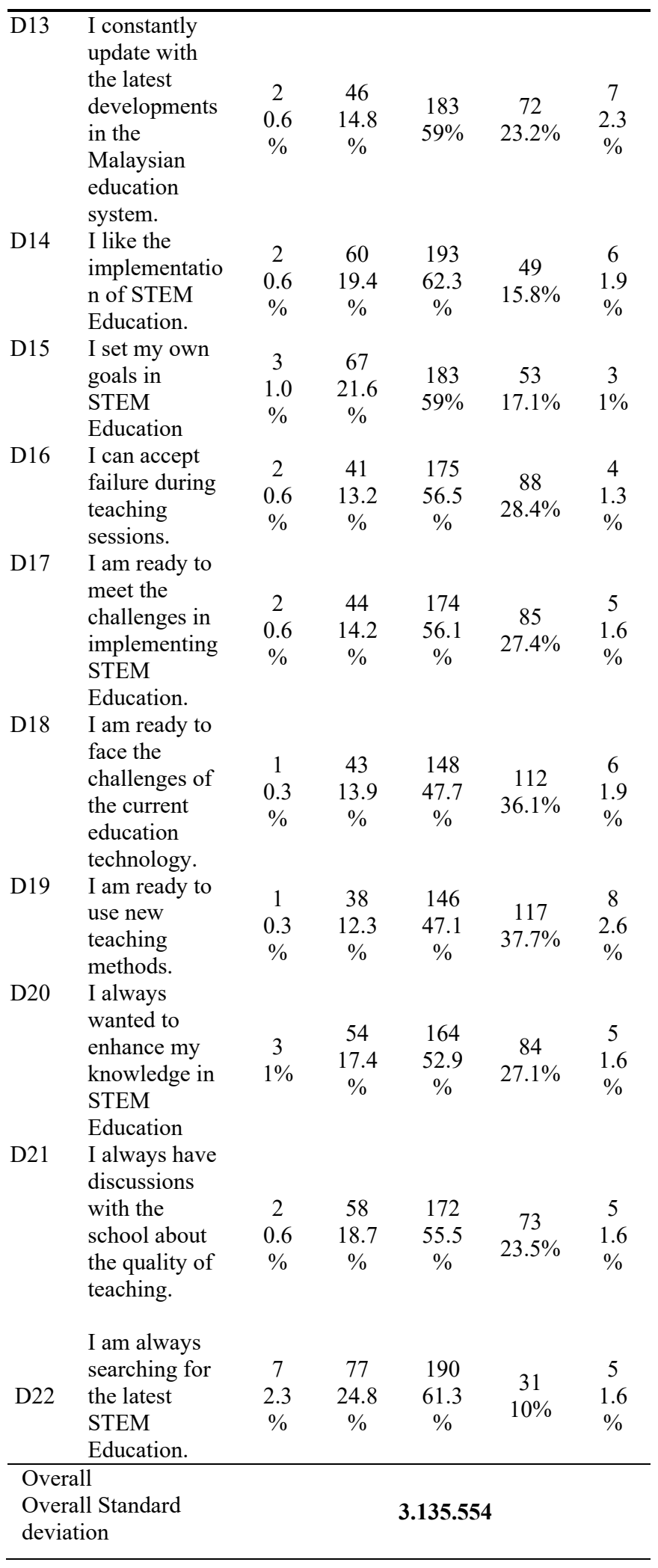

The second research question concerns the different aspects of the attitude of the mathematics teacher towards the implementation of STEM Education based on gender, namely, male and female teachers. Assumptions such as independent data scores and normally distributed data are fulfilled and proven. The Levene's tests displayed in Table 4.0 have also shown insignificant results, where the data 
variance is homogeneous. The independent t-test analysis can therefore continue.

A total of 33 male teachers and 277 female teachers answered the questionnaire. The test results showed that the mean difference score for the mathematics teachers' attitude based on the analysis was not significant, $t(308)=1.684, p=.093$. These findings indicate that there is no significant difference between the mean scores of mathematics teachers' attitudes by gender towards STEM education implementation. The results of the t-test analysis of the attitudes of different mathematics teachers' gender are shown in Table 5.0.

Table 4. Levene test results for Attitude construction.

\begin{tabular}{lll}
\hline & Levene Statistics & Sig \\
\hline Attitude & .293 & .589 \\
\hline$*$ Significant at 0.05 level &
\end{tabular}

Table 5. Results of independent t-test by gender for the mathematics Teachers'attitude

\begin{tabular}{|c|c|c|c|c|c|c|c|}
\hline 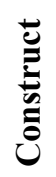 & Gender & $\mathbf{N}$ & Mean & S.D & $\mathbf{t}$ & df & Sig \\
\hline 胥 & $\begin{array}{l}\text { Male } \\
\text { Female }\end{array}$ & $\begin{array}{c}33 \\
277\end{array}$ & $\begin{array}{l}3.288 \\
3.116\end{array}$ & $\begin{array}{l}.668 \\
.537\end{array}$ & 1.68 & 308 & .09 \\
\hline
\end{tabular}

* Significant at 0.05 level

\section{Discussion}

The main objective of this study was to determine the level of mathematics teachers' attitudes towards the implementation of STEM education in primary school. This is because their attitude will have a major effect on the mathematics teacher's behavior in preparation to become a STEM teacher [25]. The results of this research should be viewed as a first step in the advancement of STEM education in schools [29], especially for primary schools. Therefore, this study was conducted with the hope of explaining the phenomenon of whether primary school mathematics teachers are prepared to implement STEM education in the aspect of attitude.

The findings show that the attitude of mathematics teachers is at a moderate level. This result is consistent with the previous research that teachers are worried and less confident when asked to teach STEM in the classroom [4]. The behavior of STEM teachers in delivering their teaching would be affected if their attitude towards achieving the goal is not in line with their understanding. More than $90 \%$ of teachers in the previous study agreed that strong knowledge and skills enhance their confidence and attitude towards STEM teaching [26]. Therefore, STEM knowledge and expertise of the 21 st century will then be passed on to educators, whether preservice teachers or teachers who have taught in schools to understand and accept STEM education sincerely [18]. On top of that, positive attitudes such as confidence and motivation will improve with the attainment of STEM education targets.

This idea is somewhat contrary to the current Malaysian national education system. Teachers are still given specialized training in STEM subjects separately. They have no formal training experience related to STEM teaching [22] and it is expected that the level of teacher's attitude will decline if no follow-up actions are taken. They want more [9] and the right equipment [22] to become a quality STEM teacher. The opportunity to gain more experience and knowledge is an added value to those who will be part of the STEM Education system. Moreover, it is found that a positive attitude is expressed and provides them further understanding of STEM after it is delivered [26].

Previous studies have shown that male teachers have higher confidence than female teachers [17]. Female teachers, on the other hand, are found to have a greater awareness and desire to teach STEM compared to male teachers [19]. Nevertheless, most prior research is consistent with the results of this current study; with no significant differences by gender [11]. Gender aspects were also found to have no significant differences in STEM [5] and no relevance to gender aspects in STEM [9].

These findings can be explained by the fact that mathematics teachers are technical teachers who are not biased in STEM education by their gender which often includes technical subject matters. This modest attitude reflected the scenario that both male and female mathematics teachers were not yet ready to teach STEM, thus no significant differences were found in the sample. Gender is not a major factor in the process of achieving STEM Education's success because the job of a teacher is dominated by female teachers. The disparity in the number of teachers by gender may have led to the results. Therefore, further studies to explore the variations between the genders of teachers should be performed in greater depth using a larger range of samples and specifying the number of each gender so that comparisons can be easily identified.

The results indicate that the attitude of a moderatelevel mathematics teacher requires follow-ups. The first implication of the study is the curriculum review of the teacher's program. The current Malaysian education curriculum still does not fulfill the goals of STEM education. The four disciplines are still taught separately, and teachers are trained by mastering one 
of them as their major in the specialization. Preservice teachers are not exposed to the STEM education institution, besides, they are already busy with their careers and occupied with their education matters. The government's desire to produce a new generation of knowledgeable and skilled in STEM does not match the reality of the education system particularly to provide STEM teachers or STEM students. The issue is not only about comprehensive analysis, but also about finding a solution by the curriculum redevelopment following the aims of STEM education. A new curriculum needs to be developed for pre-service teachers [30], so they are ready to deliver STEM. Students also need STEM subjects in their school to provide them with the opportunity to learn about STEM and thereby grow their interests.

Besides, the attitude of teachers should also be developed through the efforts of respective parties. Schools and ministries should work together to motivate primary school teachers, especially mathematics teachers who are closely linked to STEM disciplines to be positive about STEM implementation. Studies should be undertaken to determine the root causes of moderate mathematics teachers' attitudes and optimal approaches to help mathematics teachers shape and improve their attitudes towards educational reform. The goal of STEM education is believed to be achieved by the positive attitude in the teacher and they will play their part in implementing this educational transformation.

This study must be interpreted in light of certain limitations. The first limitation is that the core structure of this research is focused only on the attitude of a teacher. While attitudes are not the main construct that concerns, but knowledge and skills constructs are also important in developing the phenomenon of a quality STEM teacher. Other than that, this study mainly used questionnaire instruments to evaluate the research questions. This data collection requires support from other shreds of evidence such as observations, interviews, and others to reduce the distortion of the findings. Limitations on the sample size of the study should also be acknowledged to improve the validity and reliability of the results. The sample size of the study can be increased, and the sample amount of gender can also be specified. Thus, the research questions that analyse the mean difference of teachers' attitudes based on gender can be reliably examined and the outcomes of future studies can have a major influence on the findings of this research.

\section{Conclusion}

In conclusion, this research analyzing the level of Hulu Langat primary school teachers' attitude towards STEM education was found to be at a moderate level. The findings also show that there is no significant difference between male and female teachers in STEM education. Further studies should be conducted to ascertain the cause for this result and discuss possible ways to further develop the attitudes of mathematics teachers towards STEM education. For this reason, teachers with a positive attitude and high awareness towards the importance of STEM education [20] are crucial in this era of educational transformation. Positive attitudes can lead to positive behaviours such as being more motivated and confident in the implementation STEM education. Teachers' mindset has to be transformed according to the expected learning outcome in STEM. Efforts by all parties are essential to the success of STEM education in Malaysia in order to produce competitive generation in future.

\section{Acknowledgement}

This research was funded by the Faculty of Education, Universiti Kebangsaan Malaysia grant GG-2019-065 and PP-FPEND-2020.

\section{References}

[1]. Abdullah, A. H., Hamzah, M. H., Hussin, R. H. S. R., Kohar, U. H. A., Abd Rahman, S. N. S., \& Junaidi, J. (2017, December). Teachers' readiness in implementing science, technology, engineering and mathematics (STEM) education from the cognitive, affective and behavioural aspects. In 2017 IEEE 6th International Conference on Teaching, Assessment, and Learning for Engineering (TALE) (pp. 6-12). IEEE.

[2]. Abdulrauf, A. A., Abdul Hamid, N., \& Ishak, M. S. (2016). An exploratory data analysis on social media and youth online political participation in Nigeria and Malaysia. International Journal of Multidisciplinary Approach \& Studies (IJMAS), 3(1), 47-59.

[3]. Alkhateeb, M. A. (2018). The degree practices for mathematics teachers STEM education. Cypriot Journal of Educational Sciences, 13(3), 360-371.

[4]. Bagiati, A., \& Evangelou, D. (2015). Engineering curriculum in the preschool classroom: the teacher's experience. European Early Childhood Education Research Journal, 23(1), 112-128. doi:10.1080/1350293X.2014.991099

[5]. Bakırcı, H., \& Karışan, D. (2017). Investigating the preservice primary school, mathematics and science teachers' stem awareness. Journal of Education and Training Studies, 6(1), 32-42. doi:10.11114/jets. v6i1.2807 
[6]. Beheshti, M., Taspolat, A., Kaya, O. S., \& Sapanca, H. F. (2018). Characteristics of Instructional Videos. World Journal on Educational Technology: Current Issues, 10(1), 61-69. Retrieved from https://files.eric.ed.gov/fulltext/EJ1170366.pdf [Accessed: 16 January 2020]

[7]. Blackley, S., \& Howell, J. (2015). A STEM narrative: 15 years in the making. Australian Journal of Teacher Education, 40(7), 8.

[8]. Breiner, J. M., Harkness, S. S., Johnson, C. C., \& Koehler, C. M. (2012). What is STEM? A discussion about conceptions of STEM in education and partnerships. School Science and Mathematics, 112(1), 3-11. doi:10.1111/j.1949-8594.2011.00109.x

[9]. Çevik, M., \& Özgünay, E. (2018). STEM Education through the Perspectives of Secondary Schools Teachers and School Administrators in Turkey. Asian Journal of Education and Training, 4(2), 91-101. doi:10.20448/journal.522.2018.42.91.101

[10]. Dailey, D., Bunn, G., \& Cotabish, A. (2015). Answering the call to improve STEM education: A STEM teacher preparation program. Journal of the National Association for Alternative Certification, 10(2), 3-16.

[11]. Dejonckheere, P. J., De Wit, N., Van de Keere, K., \& Vervaet, S. (2016). Exploring the Classroom: Teaching Science in Early Childhood. International Electronic Journal of Elementary Education, 8(4), 537-558. doi:10.12973/eu-jer.5.3.149

[12]. Fitzallen, N. (2015). STEM Education: What Does Mathematics Have to Offer?. Mathematics Education Research Group of Australasia.

[13]. Golding, J. (2018). Mathematics education in the spotlight: Its purpose and some implications. London Review of Education, 16(3), 460-473.

[14]. Hedlin, M., \& Gunnarsson, G. (2014). Preschool student teachers, technology, and gender: positive expectations despite mixed experiences from their own school days. Early Child Development and Care, 184(12), 1948-1959. doi:10.1080/03004430.2014.896352

[15]. Shahali, E. H. M., Halim, L., Rasul, M. S., Osman, K., \& Zulkifeli, M. A. (2016). STEM learning through engineering design: Impact on middle secondary students' interest towards STEM. EURASIA Journal of Mathematics, Science and Technology Education, 13(5), 1189-1211.

[16]. Lee, M. H., Hsu, C. Y., \& Chang, C. Y. (2019). Identifying Taiwanese teachers' perceived selfefficacy for science, technology, engineering, and mathematics (STEM) knowledge. The Asia-Pacific Education Researcher, 28(1), 15-23. doi:10.1007/s40299-018-0401-6

[17]. Jamil, F. M., Linder, S. M., \& Stegelin, D. A. (2018). Early childhood teacher beliefs about STEAM education after a professional development conference. Early Childhood Education Journal, 46(4), 409-417. doi:10.1007/s10643-017-0875-5.
[18]. Karisan, D., Macalalag, A., \& Johnson, J. (2019). The Effect of Methods Course on Preservice Teachers' Awareness and Intentions of Teaching Science, Technology, Engineering, and Mathematics (STEM) Subject. International Journal of Research in Education and Science, 5(1), 22-35.

[19]. Akran, S. K., \& Asiroglu, S. (2018). Perceptions of Teachers towards the STEM Education and the Constructivist Education Approach: Is the Constructivist Education Approach Preparatory to the STEM Education?. Universal Journal of Educational Research, 6(10), 2175-2186.

doi:10.13189/ujer.2018.061016

[20]. Kurup, P. M., Li, X., Powell, G., \& Brown, M. (2019). Building future primary teachers' capacity in STEM: based on a platform of beliefs, understandings and intentions. International Journal of STEM Education, 6(1), 10. doi:10.1186/s40594-019-0164-5

[21]. Lucietto, A., Russell, L., \& Schott, E. (2018). STEM educators, how diverse disciplines teach. Journal of STEM Education, 19(3).

[22]. English, L. D. (2016). STEM education K-12: Perspectives on integration. International Journal of STEM education, 3(1), 3. doi:10.1186/s40594-0160036-1

[23]. Mariani, A., \& Ismail, Z. (2013). Pengaruh Kompetensi Guru Matematik Ke Atas Amalan Pengajaran Kreatif. In 2nd International Seminar on Quality and Affordable Education (ISQAE 2013) (pp. 181-187).

[24]. Mishra, P., Pandey, C. M., Singh, U., Gupta, A., Sahu, C., \& Keshri, A. (2019). Descriptive statistics and normality tests for statistical data. Annals of cardiac anaesthesia, 22(1), 67.

doi:10.4103/aca.ACA

[25]. Murcia, K., \& Pepper, C. (2018). Evaluating the social impact of a science centre's STEM professional learning strategies for teachers. Issues in Educational Research, 28(2), 438-452.

[26]. Neilson, T. (2011). King of charcoal: Japanese create new life for dying industry. Inwood Magazine, 96, 3233

[27]. Paulsen, C. A., \& Andrews, J. R. (2014). The effectiveness of placing temporal constraints on a transmedia STEM learning experience for young children. E-Learning and Digital Media, 11(2), 204213. doi:10.2304/elea.2014.11.2.204

[28]. Phang, F. A., Abu, M. S., Ali, M. B., \& Salleh, S. (2014). Faktor penyumbang kepada kemerosotan penyertaan pelajar dalam aliran sains: satu analisis sorotan tesis. Sains Humanika, 2(4).

[29]. Ring, E. A., Dare, E. A., Crotty, E. A., \& Roehrig, G. H. (2017). The evolution of teacher conceptions of STEM education throughout an intensive professional development experience. Journal of Science Teacher Education, 28(5), 444-467. doi:10.1080/1046560X.2017.1356671

[30]. Rinke, C. R., Gladstone-Brown, W., Kinlaw, C. R., \& Cappiello, J. (2016). Characterizing STEM teacher education: Affordances and constraints of explicit STEM preparation for elementary teachers. School Science and Mathematics, 116(6), 300-309. 